\title{
The Influence of Stimulation Techniques on the Microbiological Changes and n-Alkane Transitions in the Soil Contaminated of Petroleum-Derived Substances
}

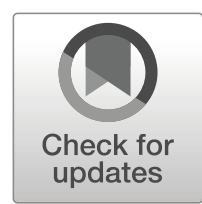

\author{
Marcin Konieczny (D) - Teresa Krzyśko-Lupicka
}

Received: 31 August 2018 / Accepted: 22 February 2019/Published online: 13 March 2019

(C) The Author(s) 2019

\begin{abstract}
Removal of petroleum products from contaminated soil is a long-term process requiring attention and constant monitoring. The aim of this study was to determine the effect of Fyre-Zyme enzyme preparation and/or calcium carbonate on microbiological changes and conversion of n-aliphatic hydrocarbons in soil contaminated of petroleum-derived substances. The material for testing was soil contaminated with petroleum substances. The total concentration of n-alkanes with a C8-C40 chain length was $420.1 \mathrm{mg} \cdot \mathrm{kg}^{-1} \mathrm{DM}$. The pot tests were carried out by introducing stimulators. As a decomposition promoter for n-alkanes in contaminated soil, a $6 \%$ water solution of Fyre-Zyme and/or $1 \%$ sterile $\mathrm{CaCO}_{3}$ was used. The pots were incubated at $25^{\circ} \mathrm{C}$ for 21 days. The dynamics of changes in the microbiota and concentration of n-alkanes were controlled for 21 days, every 7 days taking soil for testing. Microbiological tests included determining the total number of bacteria and fungi. Chemical analysis was performed by chromatographic method. Stimulating of soil bioremediation of contaminated hydrocarbons with calcium carbonate increased the number of bacteria, and stimulation with
\end{abstract}

\footnotetext{
M. Konieczny $(\bowtie)$

Institute of Biology, Faculty of Natural and Technical Science, University of Opole, 22 Oleska Street, 45-052 Opole, Poland e-mail:104949@student.uni.opole.pl

T. Krzyśko-Łupicka

Institute of Biotechnology, Faculty of Natural and Technical

Science, University of Opole, 6A Kominka Street, 45-035 Opole, Poland

e-mail: teresak@uni.opole.pl
}

Fyre-Zyme and calcium carbonate - the number of filamentous fungi. There was no significant correlation between the concentration of $n$-alkanes in the soil and the total number of bacteria and fungi but stimulating of soil bioremediation with calcium carbonate increased the number of bacteria, and stimulation with FyreZyme and calcium carbonate - the number of filamentous fungi. The observed correlations indicate that the concentration of n-alkanes in the contaminated soil increases with the addition of Fyre-Zyme.

Keywords Bioremediation $\cdot \mathrm{N}$-aliphatic hydrocarbons . Soil $\cdot$ Fyre-Zyme preparation $\cdot$ Calcium carbonate

\section{Introduction}

Along with the very rise of crude oil demand as well as its derivatives (Cirovic et al. 2015), the problem of ground and water contamination appears regularly in all industrial countries (Nowak 2008; Gateuille et al. 2014). Petroleum substances get down into soils as a result of the crude oil extraction and its process in refineries, breakdown of fuel warehouses, and seepages from pipelines - the infrastructure of the oil-burning sector (Janusz 2013, Abdel-Shafy and Mansour 2016, Banerjee and Ghoshal 2017). In soils, they might be spread in a form of substances flowing on a soil solution surface, hydrocarbons dissolved in water or absorbed on soil particles or aerosols. The substances' spreading depends on their properties as well as structure, 
granulation, and soil porosity (Ziółkowska and Wyszkowski 2008).

The petroleum-related substances which contaminate the environment belong to a group of dangerous wastes, extremely toxic for people, animals, and plants (Beak et al. 2006; Mendrycka et al. 2013; Alrumman et al. 2015). The contaminated soil caused by hydrocarbons (aliphatic, monoaromatic, and polycyclic aromatic hydrocarbons (WWA)) lead to a biological balance disturbance in the result of an increase of organic carbon amount and the assimilable forms of nitrogen, phosphorus, and potassium deficit. As an effect, a metabolism dysfunction and retardation of plant vegetation is observed, in extreme cases - even plants dieback because of inhibition in drawing of water, minerals, nutritious substances, and the oxygen too (Krosowiak et al. 2008; Pawełczak et al. 2015).

The processes of contamination removal or precipitation of hydrocarbons' decay deriving from crude oil are conducted with the use of different techniques and with different effectiveness. By these, chemical, physicochemical, and biological methods are meant, which include photodegradation as well as biodegradation in the in situ or ex situ conditions (Ziółkowska and Wyszkowski 2008; Lal et al. 2010; Rosik-Dulewska et al. 2015; Azubuike et al. 2016). Biodegradation of petroleum substances hydrocarbons can be limited by many factors, among others are autochthonous microbiota, the accessibility of biogenic compounds, the environment reaction, temperature, humidity, the accessibility of oxygen, physicochemical properties of soil, and by a type as well as the contamination intensity (Pala et al. 2006). In order to increase the biodegradation effectiveness, various bioremediation techniques can be applied, by using living organisms, their parts, metabolites, and enzymes for contamination removal (Marchut-Mikołajczyk et al. 2013) and supporting the soil microbiota growth by adding nutritious substances and/or oxygenation, emulsifying agents or surfactants which lead to the growth of contamination bioavailability for microorganisms (Cebula and Rajca 2014). Microorganisms which are elements of vaccines composition should be characterized by resistance to the contamination type and concentration, the ability of quick propagating in the environment and competitivity to soil microbiota (Mrozik and Piotrowska-Seget 2010; Dellagnezze et al. 2014). Independently on the bioremediation method applied, the toxic substances decay takes place with the participation of enzymes produced by microorganisms. The level of soil bioremediation depends on the catalytic efficiency of the enzymes present in the microorganisms' cells or in the induced ones, developed towards particular substrates (Csutak et al. 2010; Lal et al. 2010; Krzyśko-Łupicka and Robak 2011; Krzyśko-Łupicka and Kręcidło 2018). Organic compounds degradation in the environments contaminated by hydrocarbons has been conducted by three groups of microorganisms, isolated from crude oil and liquids extracted out of mining processes: fermentative bacteria, bacteria responsible for sulfates (BRS) reduction, which completely oxygenate organic compounds to carbon dioxide or incompletely to acetate and metanotrophic archeons, which produce $\mathrm{CH}_{4}$ (Wolicka 2010; Jankowska and Swędrzyńska 2016). $\mathrm{CO}_{2}$ and $\mathrm{H}_{2} \mathrm{O}$ are the results of complete degradation of aliphatic hydrocarbons.

Despite the participation of various autochthonous microorganisms in the process of reducing petroleum substances from the environment, only $0.01-1 \%$ of the general number of soil bacteria displays the ability of hydrocarbons biodegradation. Therefore, to increase the level of effectiveness and shorten the time of refining contaminated grounds, biopreparations in the form of biomass or immobilized cells of microorganisms are used or enzymatic preparations (Mrozik and PiotrowskaSeget 2010; Robak et al. 2011; Krzyśko-Łupicka and Kręcidło 2018). Preparations containing enzymatic complexes or single biocatalyzers capable of structure modification, reduction of a toxic contamination features, and in special cases - of conducting a complete mineralization of organic compounds to harmless, inorganic final products (Whiteley and Lee 2006). In view of the fact that these enzymes are simpler systems than total organisms, enzymatic bioremediation becomes a more attractive tool in the environment biotechnology.

New solutions are continuously being searched for, which obviously require testing in the laboratory scale and defining the mechanisms of operation in the first place.

The aim of the study was to assess the influence of an enzymatic preparation Fyre-Zyme and/or calcium carbonate on the microbiological processes and $n$-aliphatic hydrocarbons in the soil contaminated of petroleumderived substances. 


\section{The Material and Research Methods}

\subsection{The Experimental Design}

The material used for the research was soil $(\mathrm{pH} 7.7)$ contaminated by petroleum substances in a form of greasy, black mass and a characteristic fragrance. The samples of contaminated soils were collected from the loam sand of land at a depth of $0.3-1.0 \mathrm{~m}$, in the on the site of a former refinery in south Poland $(49.87378 \mathrm{~N}$, $19.02533 \mathrm{E}$ ). The total nitrogen and carbon were $\mathrm{N}_{\text {tot. }}$ 0.21 and $C_{\text {tot. }} 0.45 \mathrm{~g} \cdot \mathrm{kg}^{-1}$, respectively. The content of petroleum-derived substances was approximately $1010 \mathrm{mg} \cdot \mathrm{kg}^{-1} \mathrm{DM}$ including $420.1 \mathrm{mg} \cdot \mathrm{kg}^{-1} \mathrm{DM}$ of $\mathrm{n}-$ alkanes with $\mathrm{C} 8$-C40 chain length. After sampling, the soil was dried at room temperature for 4 days, passed through a $2-\mathrm{mm}$ sieve, and stored at $4{ }^{\circ} \mathrm{C}$ in the dark before use in experiments. The pot tests were set up in four replications. One kilogram of contaminated soil and stimulators presented in Table 1 was put to every pot. As stimulators of n-alkanes decomposition in contaminated soil, $6 \%$ of a preparation water solution Fyre-Zyme of the International Enzymes brand was used (Krzyśko-Łupicka et al. 2013) and/or $1 \%$ of sterile $\mathrm{CaCO}_{3}$. Fyre-Zyme consists of enzymes with the addition of biosurfactants, whose role is to facilitate the desorption of petroleum substances in the soil and stimulate microorganisms to degrade released products. In addition, the preparation is enriched with simple sugars, amino acids and additional growth factors. Both the test soil and the soil with stimulators were precisely mixed and incubated (without any covering) in the temperature of $25^{\circ} \mathrm{C}$ for 21 days. In all

Table 1 The experimental design

\begin{tabular}{ll}
\hline Object & The assay's composition \\
\hline $\mathrm{C}$ & $\begin{array}{c}\text { Soil contaminated by petroleum derivatives, } \\
\text { without stimulators (test) } \\
\text { FZ }\end{array}$ \\
& $\begin{array}{c}\text { Soil contaminated by petroleum derivatives } \\
\text { stimulated with one dose of } 6 \% \text { of the } \\
\text { preparation water solution Fyre-Zyme in the } \\
\text { amount of } 10 \%(\mathrm{~m} / \mathrm{m})\end{array}$ \\
$\mathrm{Ca}$ & $\begin{array}{c}\text { Soil contaminated by petroleum derivatives } \\
\text { stimulated with CaCO }\end{array}$ \\
& Soil contaminated by petroleum derivatives \\
FZ+Ca & stimulated with one dose of $6 \%$ preparation \\
& water solution Fyre-Zyne in the amount of \\
& $10 \%(\mathrm{~m} / \mathrm{m})$ i CaCO $\mathrm{CO}_{3}(1 \%)$
\end{tabular}

the essays, constant humidity level was obtained, adding the same water amount $-50 \mathrm{~cm}^{3}$ every 2 days ${ }^{\circ} \mathrm{C}$.

The dynamics of microbiota strength changes and the n-alkanes concentration was being controlled for 21 days; every 7 days, $1 \mathrm{~g}$ of soil was drawn in order to carry out the analysis of microbiological composition changes under the influence of the stimulators activity ( $\mathrm{FZ}$ and/or $\mathrm{CaCO}_{3}$ ) and $5 \mathrm{~g}$ of soil to use for chemical analysis. The test assay was also studied on a day, when the experiment was put into start.

\subsection{The Microbiological Analysis}

The microbiological analysis was carried out with a Koch's tenfold dilution method on the basis of Biomaxima company, according to the scheme provided in Table 2.

The number of microorganisms was expressed as a logarithm of units creating colonies $\mathrm{CFU} \cdot \mathrm{g}^{-1} \mathrm{DM}$ of soil. Diversified bacteria colonies were divided into morphological groups by using the Gram's stain technique and fungi were classified on the basis of their morphological features, using diagnostic keys (Barnett et al. 2002).

\subsection{The Chemical Analysis}

The chemical analysis included:

- Indication of soil acidity submitted to remediation in the $\mathrm{KCl}\left(\mathrm{pH}_{\mathrm{KCl}}\right)$ solution by the potentiometric method, with the use of $\mathrm{pH}-$ meter of the N-512 type, ELPO company

- Indication of dry mass in the room temperature

- Chromatographic analysis GC/MS

The process of extraction from contaminated soil was conducted in an automatic extractor fexIKA ${ }^{\circledR}$ of the IKA brand-Werke with the use of n-hexane (POCH GC grade). Both the quantitative and the qualitative analysis of n-alkanes extracts were conducted by the gas chromatography method, with the usage of gas chromatograph SHIMADZU GC 17A coupled with the mass detector MS-QP5000, in the following conditions: capillary column VF1, ms of the length $30 \mathrm{~m}$; ID $0.53 \mathrm{~mm}$ and if $1.50 \mu \mathrm{m}$, the flow of carrier gas (He), $3 \mathrm{~cm}^{3}$ per minute; the batcher temperature, $300{ }^{\circ} \mathrm{C}$; detector's temperature, $325^{\circ} \mathrm{C}$. The temperature program: 100-3/12/320-12.; detector's power MS from 1.2 
Table 2 The microbiological analysis methods

\begin{tabular}{llll}
\hline Groups of microorganisms & Medium & \multicolumn{2}{l}{ Culture conditions } \\
\cline { 2 - 4 } & & Time $[\mathrm{h}]$ & Temperature $\left[{ }^{\circ} \mathrm{C}\right]$ \\
\hline Total number of bacteria & Nutrient agar & 24 & 25 \\
Total number of yeast & Sabouraud agar with chloramphenicol & 72 & 25 \\
Total number of fungi & Czapek agar & & 25 \\
\hline
\end{tabular}

to $1.4 \mathrm{kV}$. The amount of $\mathrm{n}$-alkanes in soil extracts was defined on the basis of file collection covering the boiling point range $126-522{ }^{\circ} \mathrm{C}$ (n-alkanes from $\mathrm{C} 8$ (octane) to $\mathrm{C} 40$ (tetraoctane)). The quantitative composition of aliphatic hydrocarbons were provided in $\mathrm{mg} \cdot \mathrm{kg}^{-1} \mathrm{DM}$ of soil.

\subsection{Statistical Analysis}

To assess the relationship between the concentrations of $\mathrm{n}$-alkanes in soil and time and the change in the number of microbiota, statistical analysis was performed by Pearson correlation analysis in the software Statistica 13.1 (Dell Software, Round Rock, USA).

\section{Results}

From the soil contaminated with petroleum substances on the day when the experiment was put into start, $2.8 \cdot 10^{6} \mathrm{CFU} \cdot \mathrm{g}^{-1} \mathrm{DM}$ of bacteria, $1.6 \cdot 10^{4} \mathrm{CFU} \cdot \mathrm{g}^{-1} \mathrm{DM}$ of fungi and no yeast was found. In dependence on the time of the experiment as well as on the stimulators applied, the quantity of microorganisms in the contaminated soil visibly changed. At the beginning in all the objects, in comparison to the control, almost tenfold rise of the bacteria number was observed and later their hundredfold decrease in the objects with an extra amount of the Fyre-Zyme (FZ and FZ+Ca) preparation. The highest number of bacteria was noted in the objects stimulated with calcium carbonate (Ca) (Fig. 1a). In the case of the fungi, in comparison to the control, the number was rising from 10 to 15 times in the objects with the extra amount of Fyre-Zyme (FZ and FZ+Ca), preparation and the additional amount of calcium carbonate $(\mathrm{Ca})$ did visibly stopped their growth (Fig. 1b.). The dominant groups of fungi belonged to the Penicillium, Aspergillus, and Fusarium strains.
The analysis of Pearson's correlation does not show any significant correlation between the concentration of $\mathrm{n}$-alkanes in the soil and total number of microorganisms. The described correlations, both positive and negative, can be explained by different rates of hydrocarbon metabolism and different tolerance to aromatic hydrocarbons (Table 3). In the case of fungi, it was not possible to show the influence of hydrocarbons on their development.

In the course of the experiment, both in the test object (C) and in the test stimulated with the Fyre-Zyme (FZ) preparation and the Fyre-Zyme preparation and the calcium carbonate $(\mathrm{FZ}+\mathrm{Ca})$, there was a noticeable domination of gram-positive bacteria. However, in the objects treated only with calcium carbonate $(\mathrm{Ca})$, the advantage was obtained by the gram-negative bacteria (Table 4).

The microbiological changes were accompanied with the changes of $\mathrm{pH}$ and chemical composition of the analyzed samples, being the effect of enzymes and/or $\mathrm{CaCO}_{3}$ stimulation activities. In the presence of stimulators, the soil $\mathrm{pH}$ in comparison to the control sample increased but after 21 days decreased and remained on the level of $\mathrm{pH} 8$ (Fig. 2).

The total content of n-alkanes (C8-C40) in the contaminated soil, dependently on the stimulation applied, underwent changes in the duration time of the process (Fig. 3). The lowest total n-alkane content was noted after 14 days of process after stimulated with $\mathrm{CaCO}_{3}$. The Fyre-Zyme preparation was the most effective one only during the first 7 days, then a fourfold increase of n-alkanes concentration was observed. Nevertheless, after 3 weeks of bioremediation in the stimulated objects, a significant increase of n-alkanes was noted, in comparison to the control (C) - fourfold after stimulation with FZ, threefold after $\mathrm{FZ}+\mathrm{Ca}$ stimulation, and one and a half fold after $\mathrm{CaCO}_{3}$ stimulation, what may point at local desorption and diffusion of hydrocarbons from a soil 

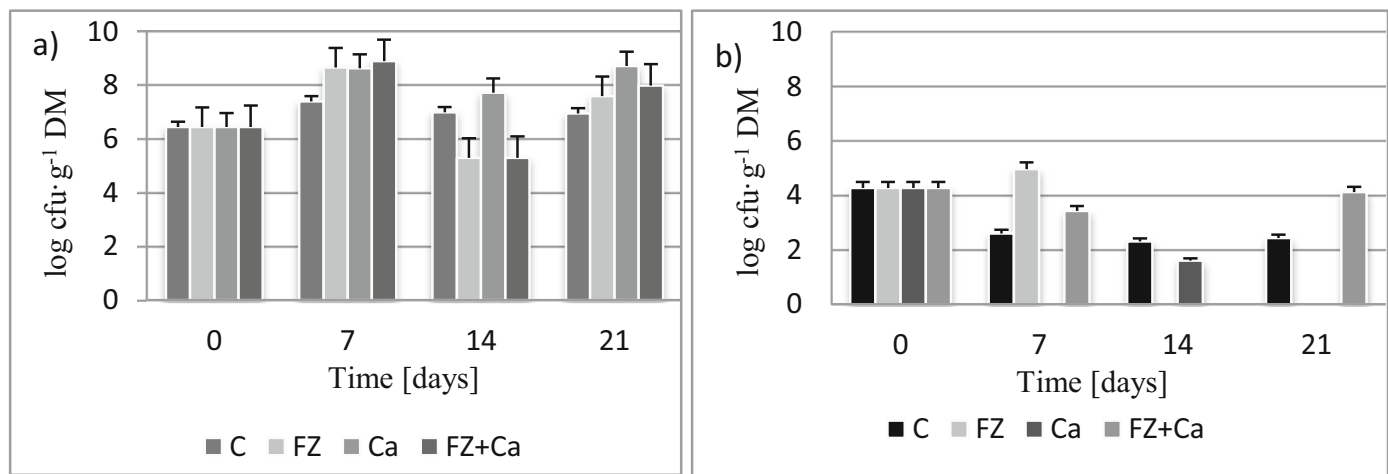

Fig. 1 Dynamics of changes of microbiota number $\left[\log \mathrm{CFU} \cdot \mathrm{g}^{-1} \mathrm{DM}\right]$ in soil during experiment: a bacteria and $\mathbf{b}$ fungi (C, control; FZ, Fyre-Zyme; $\mathrm{Ca}, \mathrm{CaCO}_{3} ; \mathrm{FZ}+\mathrm{Ca}$, Fyre-Zyme+CaCO 3 )

complex. Simultaneously, twofold decrease of nalkanes was observed in control.

Table 5 shows a significant positive correlation between the concentration of n-alkanes in soil and time. In addition, the presented data confirm a significant relationship between the concentration of n-alkanes in the soil and time of bioremediation. The observed correlations indicate that the concentration of n-alkanes in the soil increases with the addition of Fyre-Zyme by the distribution of aromatic hydrocarbons.

The changes concerned also the qualitative composition of $n$-alkanes in dependence on the stimulation applied (Table 6). In the contaminated soil in the largest amount of over $70 \mathrm{mg} \cdot \mathrm{kg}^{-1} \mathrm{DM}$, there were only $\mathrm{C} 16$ and $\mathrm{C} 18$ hydrocarbons, and in an amount of 10-35 mg $\cdot \mathrm{kg}^{-1} \mathrm{DM} \mathrm{C} 22, \mathrm{C} 26, \mathrm{C} 28, \mathrm{C} 24$, and $\mathrm{C} 20$ hydrocarbons. After using the FZ, changes in the content of individual hydrocarbons varied; after 7 days of the process, only the amount of $\mathrm{C} 10, \mathrm{C} 14$, and $\mathrm{C} 22$ hydrocarbons increased, and the remaining ones decreased compared to the initial soil sample. However, after 21 days of bioremediation, compared to the control, the content of $\mathrm{C} 14$ and $\mathrm{C} 40$ hydrocarbons (almost 20 times), $\mathrm{C} 16$ and $\mathrm{C} 30$ (15 times), and $\mathrm{C} 22$ (8 times) increased, and the $\mathrm{C} 28, \mathrm{C} 36$, and $\mathrm{C} 38$ hydrocarbons content decreased ( 5 times). The $\mathrm{CaCO}_{3}$ used stabilized the soil environment of the bacteria, but after 21 days of the process, no significant changes in the quantitative and qualitative content of the n-alkanes were observed compared to the control. Simultaneous stimulation of $\mathrm{CaCO}_{3}$ and $\mathrm{FZ}$ changed the intensity of the process - the overall content of n-alkanes decreased compared to the object treated only with $\mathrm{FZ}$. In the $\mathrm{FZ}+\mathrm{Ca}$ objects, in comparison to the control, the increase of short-chain hydrocarbons: C10 and C14 (40 times) and C16 (20 times). While the content of C36 and C38 decreased almost 10 times.

Table 3 Correlation coefficients between n-alkane contents and total number of bacteria

\begin{tabular}{|c|c|c|c|c|}
\hline \multirow[t]{2}{*}{ Total number of bacteria } & \multicolumn{4}{|c|}{ Content of n-alkanes } \\
\hline & $\mathrm{C}$ & $\mathrm{FZ}$ & $\mathrm{Ca}$ & $\mathrm{FZ}+\mathrm{Ca}$ \\
\hline \multirow[t]{2}{*}{ C OLB } & -0.590 & -0.185 & -0.095 & 0.429 \\
\hline & $p=0.410$ & $p=0.815$ & $p=0.905$ & $p=0.571$ \\
\hline \multirow[t]{2}{*}{ FZ OLB } & 0.056 & -0.486 & 0.672 & -0.447 \\
\hline & $p=0.944$ & $p=0.514$ & $p=0.328$ & $p=0.553$ \\
\hline \multirow[t]{2}{*}{$\mathrm{Ca}$ OLB } & -0.756 & 0.194 & -0.177 & 0.416 \\
\hline & $p=0.244$ & $p=0.806$ & $p=0.823$ & $p=0.584$ \\
\hline \multirow[t]{2}{*}{$\mathrm{FZ}+\mathrm{Ca}$ OLB } & -0.003 & -0.416 & 0.627 & -0.409 \\
\hline & $p=0.997$ & $p=0.584$ & $p=0.373$ & $p=0.591$ \\
\hline
\end{tabular}

Shown correlation significant at the level $P<0.05$ 
Table 4 The part of gram-positive and gram-negative bacteria in total population [\%], during experiment: $\mathrm{C}$, control; FZ, FyreZyme; $\mathrm{Ca}, \mathrm{CaCO}_{3} ; \mathrm{FZ}+\mathrm{Ca}$, Fyre-Zyme $+\mathrm{CaCO}_{3}$

\begin{tabular}{|c|c|c|c|c|c|c|}
\hline \multirow[t]{3}{*}{ Object } & \multicolumn{6}{|c|}{ Time [days] } \\
\hline & \multicolumn{2}{|l|}{7} & \multicolumn{2}{|l|}{14} & \multicolumn{2}{|l|}{21} \\
\hline & G+ & $\mathrm{G}^{-}$ & $\mathrm{G}+$ & $\mathrm{G}^{-}$ & $\mathrm{G}+$ & $\mathrm{G}^{-}$ \\
\hline $\mathrm{C}$ & 100.00 & 0.00 & 82.00 & 18.00 & 100.00 & 0.00 \\
\hline $\mathrm{FZ}$ & 96.96 & 3.04 & 100.00 & 0.00 & 100.00 & 0.00 \\
\hline $\mathrm{Ca}$ & 67.44 & 32.56 & 81.48 & 18.52 & 26.42 & 73.58 \\
\hline $\mathrm{FZ}+\mathrm{Ca}$ & 21.25 & 78.75 & 100.00 & 0.00 & 100.00 & 0.00 \\
\hline
\end{tabular}

\section{The Debate on the Results}

Nowadays, high level of the natural environment pollution with petroleum substances forces us to search for safe and more and more effective methods of its regeneration. The most commonly used bioremediation techniques are stimulation and/or bioaugumentation. Their aim is to increase the degradation activity of autochthonous microbiota and then stimulation or growth inhibition of some microorganisms groups, such as bacteria, actinomyces, yeast, and fungi. As enzymes constitute simpler systems than total microorganisms, enzymatic bioremediation becomes a more attractive tool in the environment biotechnology. Ho and Rashid (2008), Krzyśko-Łupicka et al. (2013), and Mysłek et al. (2016) showed that enzymatic preparations intensified the process of removing petroleum substances from contaminated soil and modified the microbiota's composition of this environment. The quantity of microorganisms as well as dynamics of their changes in the course of bioremediation can be a determinant of a biological activity and soil fertility as well as the level of its degradation (Guo et al. 2012). The obtained research results point at the fact that quantitativequalitative changes of microorganisms depend on the applied technique of the ground contamination removal. The stimulation of bioremediation contaminated with petroleum substances soil with the Fyre-Zyme preparation and the calcium carbonate was increasing the amount of fungi, what is confirmed by the studies of Nowak et al. (2008). In the group of fungi isolates of Penicillium, Aspergillus i Fusarium were dominating. Similar results were also obtained by Abdel-Shafy and Mansour (2016) and Kopytko and Ibarra Mojica (2009).

However, the stimulation with the calcium carbonate caused an increase in the autochthonous bacteria quantity, mainly the gram-negative ones. The growth in the quantity of the group is considered as one of the indicators of contamination decline (Krzyśko-Łupicka and Kręcidło 2018).

The presence of diversified microbiota in the bioremediation process guarantees a better layout of petroleum substances. By the cooperation of different bacteria species and fungi, higher level of hydrocarbons biodegradation can be achieved. Long-chain hydrocarbons (alkanes and olefins) are decayed by many species of bacteria types (Pseudomonas, Acinetobacter, Arthrobacter, Corynebacterium, Nocardia, Mycobacterium, Geobacillus), also by numerous fungi, such as Cladosporium, Aspergillus, Fusarium, and Candida (Makut and Ishaya 2010).

The n-alkane reduction on the bioremediation way takes place with the participation of enzymes, mixedfunction oxidase, and dioxygenases. In the case of
Fig. 2 The soil $\mathrm{pH}$ in the duration time of the process in dependence of the stimulation type: C, control; FZ, Fyre-Zyme; $\mathrm{Ca}, \mathrm{CaCO}_{3}$; $\mathrm{FZ}+\mathrm{Ca}$, Fyre$\mathrm{Zyme}+\mathrm{CaCO}_{3}$

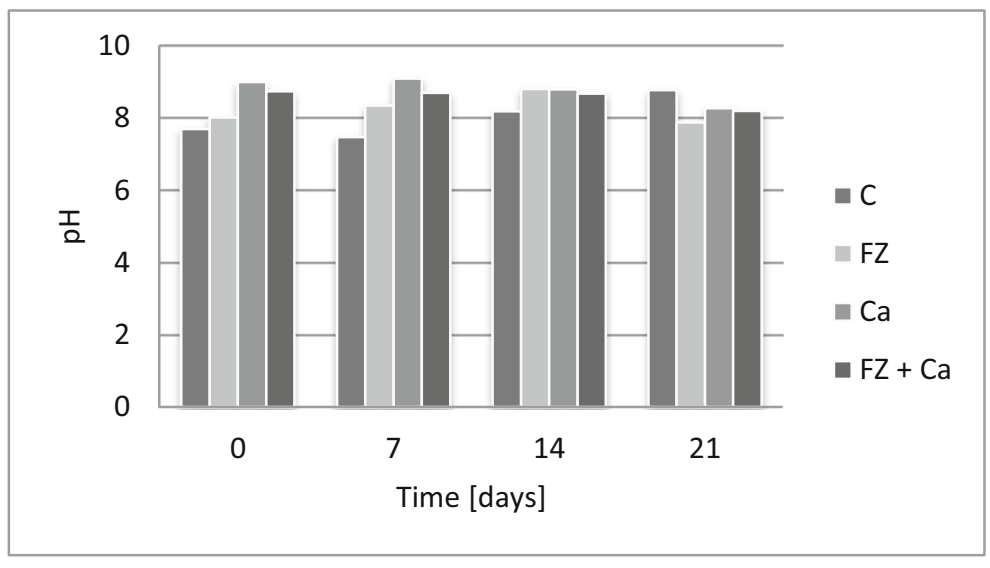


Fig. 3 Changes in the total content of n-alkanes during the time of the process, depending on the type stimulation: $\mathrm{C}$, control; FZ, Fyre-Zyme; $\mathrm{Ca}, \mathrm{CaCO}_{3}$; $\mathrm{FZ}+\mathrm{Ca}$, Fyre-Zyme+CaCO

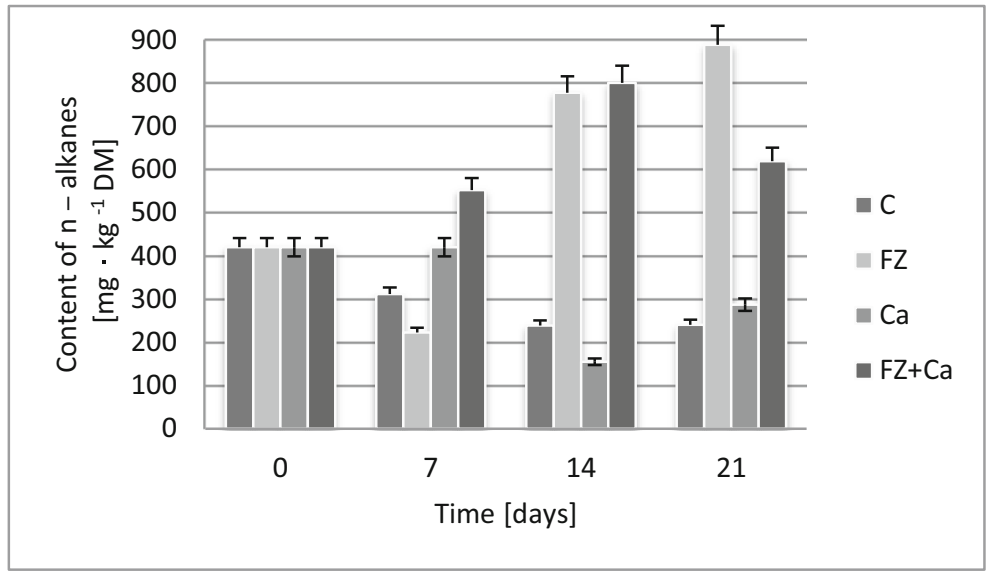

the first group of enzymes, the final methyl groups of n-alkanes become oxidized to primary alcohols, which then, in the further oxidation reactions, become transformed to aldehydes and fatty acids. Dioxygenases influence also on the final methylic groups of n-alkanes, but at the same time, they also cause incorporation of two carbon atoms to the functional group and lead to superoxide creation, which are next transformed to fatty acids. In the course of further reactions, carboxylic acids, in most cases, are transformed to acethylo-CoA, which secondly in the tricarboxylic acid cycle undergoes reduction to $\mathrm{CO}_{2}$ and $\mathrm{H}_{2} \mathrm{O}$ (Van Hamme et al. 2003; Whiteley and Lee 2006; Chikere et al. 2011). Mixtures of different enzymes, both the ones discharged by a cell as well as the intercellular ones, are responsible for decomposition of petroleum substances in soil (Alcade et al. 2006).

The transitions are accompanied with reaction changes both in the contaminated soil without any preparation as well as after adding it, what may be caused by the metabolic microorganisms activity (Krzyśko-Łupicka et al. 2013, Rosik-Dulewska et al. 2015.)

The vulnerability of n-alkanes on biodegradation depends on the chemical structure of hydrocarbons and their molecular mass; hydrocarbons degradation of the chains length $\mathrm{C} 10-\mathrm{C} 22$ takes place in the fastest way and the other groups characterized by high hydrophobicity are disintegrated in a much more difficult way (Dindar et al. 2013; Hamed et al. 2013). In our research, we have shown that the bioremediation stimulation with Fyre-Zyme preparation and with calcium carbonate was

Table 5 Correlation coefficients between the concentrations of n-alkanes and time

\begin{tabular}{|c|c|c|c|c|c|}
\hline \multirow[t]{2}{*}{ Variable } & \multirow[b]{2}{*}{ Time } & \multicolumn{4}{|c|}{ Content of n-alkanes } \\
\hline & & $\mathrm{C}$ & $\mathrm{FZ}$ & $\mathrm{Ca}$ & $\mathrm{FZ}+\mathrm{Ca}$ \\
\hline \multirow[t]{2}{*}{ Time } & 1.000 & 0.377 & 0.009 & 0.724 & 0.084 \\
\hline & $p=---$ & $p=0.623$ & $p=0.991$ & $p=0.276$ & $p=0.916$ \\
\hline \multirow[t]{2}{*}{ Content of n-alkanes C } & 0.377 & 1.000 & 0.556 & 0.855 & 0.562 \\
\hline & $p=0.623$ & $p=---$ & $p=0.444$ & $p=0.145$ & $p=0.438$ \\
\hline \multirow[t]{2}{*}{ Content of n-alkanes FZ } & 0.009 & 0.556 & 1.000 & 0.609 & $0.997 *$ \\
\hline & $p=0.991$ & $p=0.444$ & $p=---$ & $p=0.391$ & $p=0.003$ \\
\hline \multirow[t]{2}{*}{ Content of n-alkanes $\mathrm{Ca}$} & 0.724 & 0.856 & 0.609 & 1.000 & 0.652 \\
\hline & $p=0.276$ & $p=0.145$ & $\mathrm{p}=0.391$ & $p=---$ & $p=0.348$ \\
\hline \multirow[t]{2}{*}{ Content of n-alkanes $\mathrm{FZ}+\mathrm{Ca}$} & 0.084 & 0.562 & $0.997 *$ & 0.652 & 1.000 \\
\hline & $p=0.916$ & $p=0.438$ & $p=0.003$ & $p=0.348$ & $p=---$ \\
\hline
\end{tabular}

*Shown correlation significant at the level $p<0.05$ 
Table 6 Average n-alkane content in soil during experiment $\left[\mathrm{mg} \cdot \mathrm{kg}^{-1} \mathrm{DM}\right]$

\begin{tabular}{|c|c|c|c|c|c|c|c|c|c|c|c|c|c|}
\hline \multirow{3}{*}{$\begin{array}{l}\text { The number of carbon } \\
\text { atoms in the chain }\end{array}$} & \multicolumn{4}{|l|}{$\mathrm{C}$} & \multicolumn{3}{|l|}{$\mathrm{FZ}$} & \multicolumn{3}{|l|}{$\mathrm{Ca}$} & \multicolumn{3}{|c|}{$\mathrm{FZ}+\mathrm{Ca}$} \\
\hline & \multicolumn{13}{|c|}{ Time [days] } \\
\hline & 0 & 7 & 14 & 21 & 7 & 14 & 21 & 7 & 14 & 21 & 7 & 14 & 21 \\
\hline $\mathrm{C} 8$ & 3.6 & 1.1 & 0.0 & 0.0 & 1.8 & 0.2 & 0.2 & 2.3 & 1.7 & 2.3 & 0.0 & 0.0 & 0.0 \\
\hline $\mathrm{C} 10$ & 0.5 & 0.9 & 0.6 & 0.2 & 20.9 & 0.5 & 0.8 & 0.9 & 0.5 & 0.1 & 0.2 & 0.5 & 7.5 \\
\hline $\mathrm{C} 12$ & 3.2 & 1.1 & 0.8 & 0.6 & 0.8 & 0.2 & 0.2 & 1.8 & 0.6 & 0.8 & 0.6 & 0.5 & 2.2 \\
\hline $\mathrm{C} 14$ & 7.4 & 4.5 & 3.4 & 3.1 & 21.0 & 57.2 & 60.4 & 9.6 & 2.4 & 3.4 & 28.8 & 107.1 & 147.9 \\
\hline $\mathrm{C} 16$ & 76.5 & 8.2 & 3.1 & 3.0 & 7.2 & 32.8 & 49.0 & 15.6 & 2.1 & 4.0 & 14.4 & 46.8 & 56.7 \\
\hline $\mathrm{C} 18$ & 175.5 & 149.3 & 119.7 & 119.5 & 2.8 & 128.7 & 173.5 & 179.1 & 115.8 & 158.9 & 149.7 & 170.0 & 168.1 \\
\hline $\mathrm{C} 20$ & 17.4 & 14.2 & 11.5 & 12.3 & 7.5 & 12.4 & 34.0 & 17.8 & 4.7 & 12.8 & 10.0 & 18.1 & 17.5 \\
\hline $\mathrm{C} 22$ & 34.7 & 38.7 & 30.7 & 31.4 & 150.5 & 189.5 & 258.8 & 40.5 & 2.5 & 33.3 & 100.9 & 205.9 & 39.0 \\
\hline $\mathrm{C} 24$ & 17.7 & 17.1 & 13.5 & 13.8 & 3.8 & 49.8 & 54.2 & 17.3 & 5.5 & 14.0 & 28.8 & 45.8 & 41.7 \\
\hline $\mathrm{C} 26$ & 27.0 & 10.9 & 8.3 & 8.2 & 2.9 & 14.0 & 23.3 & 24.7 & 5.4 & 7.8 & 11.4 & 19.6 & 13.7 \\
\hline $\mathrm{C} 28$ & 19.9 & 21.0 & 15.2 & 16.0 & 1.4 & 4.7 & 4.2 & 19.5 & 5.6 & 16.0 & 18.8 & 19.7 & 11.0 \\
\hline $\mathrm{C} 30$ & 9.0 & 13.5 & 12.1 & 10.5 & 0.7 & 190.1 & 160.4 & 14.1 & 3.5 & 9.7 & 136.1 & 130.9 & 86.3 \\
\hline $\mathrm{C} 32$ & 8.5 & 10.0 & 3.0 & 6.1 & 0.6 & 36.2 & 24.2 & 10.0 & 1.9 & 7.2 & 4.9 & 11.2 & 3.5 \\
\hline $\mathrm{C} 34$ & 8.3 & 6.5 & 3.6 & 4.8 & 0.3 & 15.5 & 7.4 & 8.7 & 1.0 & 6.2 & 2.8 & 4.9 & 2.2 \\
\hline $\mathrm{C} 36$ & 6.3 & 7.7 & 5.1 & 6.0 & 0.1 & 2.2 & 1.6 & 6.7 & 0.3 & 6.1 & 1.7 & 1.1 & 0.7 \\
\hline C 38 & 3.1 & 4. 2 & 3.7 & 2.7 & 0.1 & 0.9 & 0.4 & 4.6 & 0.0 & 3.2 & 0.6 & 0.7 & 0.3 \\
\hline $\mathrm{C} 40$ & 1.4 & 6.7 & 4.2 & 2.0 & 0.1 & 42.7 & 36.0 & 4.2 & 1.2 & 1.3 & 43.0 & 17.7 & 21.1 \\
\hline Summary & 420.1 & 311.4 & 238.5 & 240.2 & 222.3 & 777.5 & 888.7 & 420.1 & 154.9 & 287.1 & 552.7 & 800.5 & 619.3 \\
\hline
\end{tabular}

$C$, control; $F Z$, Fyre-Zyme; $\mathrm{Ca}, \mathrm{CaCO}_{3} ; \mathrm{FZ}+\mathrm{Ca}$, Fyre-Zyme+CaCO 3

leading to a decrease of long-chain hydrocarbons content (C28, C36, and C38).

Nevertheless, the observed increase of total n-alkanes concentration is probably caused by desorption of the adsorbed molecules of petroleum substances compounds and by the cyclic compounds degradation (Sirguey et al. 2008; Robak et al. 2011; Krzyśko-Łupicka et al. 2013; Rosik-Dulewska et al. 2015; Haritash and Kaushik 2009). However, as Pawełczak et al. (2015) have proved, in the process of cleaning the soil contaminated with petroleum substances, the applied bioremediation technique has bigger influence on the plants' growth than the level of contamination with hydrocarbons.

\section{Conclusions}

1. There was no significant correlation between the concentration of n-alkanes in the soil and the total number of bacteria and fungi but stimulating of soil bioremediation with calcium carbonate increased the number of bacteria, and stimulation with Fyre-Zyme and calcium carbonate - the number of filamentous fungi.

2. The observed correlations indicate that the concentration of $n$-alkanes in the contaminated soil increases with the addition of Fyre-Zyme.

3. The stimulation techniques used caused an increase in the total content of n-alkanes compared to the initial concentration, the highest after stimulation with the enzyme preparation.

4. After stimulation bioremediation with FyreZyme or Fyre-Zyme and calcium carbonate, the content of long-chain hydrocarbons (C28, C36, and $\mathrm{C} 38$ ) decreased.

Open Access This article is distributed under the terms of the Creative Commons Attribution 4.0 International License (http:// creativecommons.org/licenses/by/4.0/), which permits unrestricted use, distribution, and reproduction in any medium, provided 
you give appropriate credit to the original author(s) and the source, provide a link to the Creative Commons license, and indicate if changes were made.

\section{References}

Abdel-Shafy, H. I., \& Mansour, M. S. M. (2016). A review on polycyclic aromatic hydrocarbons: source, environmental impact, effect on human health and remediation. Egyptian Journal of Petroleum, 25(1), 107-123. https://doi. org/10.1016/j.ejpe.2015.03.011.

Alcade, M., Ferrer, M., Plou, F. J., \& Ballesteros, A. (2006). Environmental biocatalysis: from remediation with enzymes to novel green processes. Trends in Biotechnology, 24, 281-287.

Alrumman, S., Paton, G., \& Standing, D. (2015). Effects of hydrocarbon contamination on soil microbial community and enzyme activity. Journal of King Saud UniversityScience, 27(1), 31-41.

Azubuike, C. C., Chikere, C. B., \& Okpokwasili, G. C. (2016). Bioremediation techniques-classification based on site of application: principles, advantages, limitations and prospects. World Journal of Microbiology and Biotechnoogy. https://doi.org/10.1007/s11274-016-2137-x.

Banerjee, A., \& Ghoshal, A. K. (2017). Bioremediation of petroleum wastewater by hyper-phenol tolerant Bacillus cereus: preliminary studies with laboratory-scale batch process. Bioengineered, 8(5), 446-450. https://doi.org/10.1080 /21655979.2016.1261224.

Barnett, J. A., Payne, R. W., \& Yarrow, D. (2002). Yeast characteristics and identification (3rd ed.). Cambridge: Cambridge University Press ISBN 9780521573962.

Beak, K. H., Yoon, B. D., Oh, H. M., Kim, H. S., \& Lee, I. S. (2006). Biodegradation of aliphatic and aromatic hydrocarbons by Nocardia sp. H17-1. Geomicrobiology Journal, 23(5), 253-259. https://doi.org/10.1080 /01490450600760633.

Cebula, J., \& Rajca, M. (2014). Cleansing soils and ground. In Cleaning of soil and ground (1st ed.). Gliwice: Silesian University of Technology Press ISBN: 978-83-7880-256-3, (in Polish).

Chikere, C. B., Okpokwasili, G. C., \& Chikere, B. O. (2011). Monitoring of microbial hydrocarbon remediation in the soil. 3 Biotech, 1(3), 117-138. https://doi.org/10.1007/s13205011-0014-8.

Cirovic, M., Makajic-Nikolic, D., Petrovic, N., Vujosevic, M., \& Kuzmanovic, M. (2015). European Union oil import dependency risk analysis. Polish Journal of Environmental Studies, 24(1), 75-81. https://doi.org/10.15244/pjoes/26105.

Csutak, O., Stoica, I., Ghindea, R., Tanase, A. M., \& Vassu, T. (2010). Insights on yeast bioremediation processes. Romanian Biotechnological Letters, 15(2), 5066-5071.

Dellagnezze, B. M., de Sousa, G. V., Martins, L. L., Domingos, D. F., Limache, E. E. G., de Vasconcellos, S. P., da Cruz, G. F., \& de Oliveira, V. M. (2014). Bioremediation potential of microorganisms derived from petroleum reservoirs. Marine Pollution Bulletin, 89(1-2), 191-200. https://doi.org/10.1016 j.marpolbul.2014.10.003.
Dindar, E., Şağban, F. O. T., \& Başkaya, H. S. (2013). Bioremediation of petroleum-contaminated soil. Journal of Biological and Environmental Sciences, 7(19), 39-47.

Gateuille, D., Evrard, O., Lefevre, I., Moreau-Guigon, E., Alliot, F., Chevreuil, M., \& Mouchel, J. M. (2014). Mass balance and decontamination times of polycyclic aromatic hydrocarbons in rural nested catchments of an early industrialized region (Seine River basin, France). Science of the Total Environment, 470-471, 608-617. https://doi.org/10.1016/j. scitotenv.2013.10.009.

Guo, H., Yao, J., Cai, M., Qian, Y., Guo, Y., Richnow, H. H., Blake, R. E., Doni, S., \& Ceccanti, B. (2012). Effects of petroleum contamination on soil microbial numbers, metabolic activity and urease activity. Chemosphere, $87(11)$, $1273-1280$. https://doi.org/10.1016/j. chemosphere.2012.01.034.

Hamed, S. B., Gam, Z. B. A., Rezgui, R., Ghram, A., Maaroufi, A., \& Labat, M. (2013). Diversity of culturable aerobic bacteria colonizing four petroleum by-products storage reservoirs. African Journal of Microbiology Research, 7(21), 2542-2549. https://doi.org/10.5897/AJMR12.1586.

Haritash, A. K., \& Kaushik, C. P. (2009). Biodegradation aspects of polycyclic aromatic hydrocarbons (PAHs): a review. Journal of Hazardous Materials, 169(1-3), 1-15. https://doi.org/10.1016/j.jhazmat.2009.03.137.

Ho, J. I., \& Rashid, M. (2008). Application of EZ-enzyme in bioremediation of oily sludge. Jurnal Teknologi, 48(1), 2132. https://doi.org/10.11113/jt.v48.231.

Jankowska, M., \& Swędrzyńska, D. (2016). Analysis of the interactions of microorganisms in soil environment. Cosmos Problems of Biological Sciences, 65(1), 49-55.

Janusz, P. (2013). The supply lines and structure of crude oil consumption in Poland between 1999 and 2011. Oil-Gas, 1, 66-77.

Kopytko, M., \& Ibarra Mojica, D. M. (2009). Biodegradation potential of total petroleum hydrocarbons in oil industry contaminated soils. Journal of the Polish Mineral Engineering Society, 2, 31-48.

Krosowiak, K., Śmigielski, K., Kwapisz, E., \& Marchut, O. (2008). Remediation of soil contaminated with petroleum hydrocarbons. Food Chemistry and Biotechnology, 72, 89-97.

Krzyśko-Łupicka, T., \& Kręcidło, Ł. (2018). Unconventional yeast in the degradation of hydrocarbons in contaminated soil. Environment Protection Engineering, 44(2), 87-99.

Krzyśko-Łupicka, T., \& Robak, M. (2011). Ability of free and immobilized Yarrowia lipolytica yeast biomass to fatty compounds in spent bleaching earth. Acta Scientiarum Polonorum Biotechnology, 10(4), 29-38.

Krzyśko-Łupicka, T., Ciesielczuk, T., \& Chwałowska, M. (2013). The biodegradation of petroleum substances in contaminated soil in presence of FYRE-ZYME preparation. Acta Scientiarum Polonorum Biotechnology, 12(1), 5-18.

Lal, R., Pandey, G., Sharma, P., Kumari, K., Malhotra, S., Pandey, R., Raina, V., Kohler, H.-. P. E., Hollinger, C., Jackson, C., \& Oakeshott, J. G. (2010). Biochemistry of microbial degradation of hexachlorocyclohexane and prospects for bioremediation. Microbioogy and Mololecular Biology Reviews, 74(1), 58-80. https://doi.org/10.1128/MMBR.00029-09.

Makut, M. D., \& Ishaya, P. (2010). Bacterial species associated with soils contaminated with used petroleum products in 
Keffi town, Nigeria. African Journal of Microbiology Research, 4(16), 1698-1702.

Marchut-Mikołajczyk, O., Kwapisz, E., \& Antczak, T. (2013). Enzymatic bioremediation of xenobiotics. Engineering and Protection of Environment, 16(1), 39-55.

Mendrycka, M., Mucha, K., \& Stawarz, S. (2013). Bioremediation of petroleum compounds and their biodegradation pathways. Advances in Microbiology, 52(4), 397-408.

Mrozik, A., \& Piotrowska-Seget, Z. (2010). Bioaugmentation as a strategy for cleaning up of soils contaminated with aromatic compounds. Microbiological Research, 165(5), 363-375. https://doi.org/10.1016/j.micres.2009.08.001.

Mysłek, M., Walkowiak, W., \& Krzyśko-Łupicka, T. (2016). The effect of enzymatic preparation dosage technique microbiological changes and transformations of aliphatic hydrocarbons in soil contaminated with hydrocarbons. In K. Kropiwiec \& M. Szala (Eds.), Selected issues in the field of environmental protection and renewable energy (pp. 130148). Lublin: TYGIEL.

Nowak, J. (2008). Bioremediation of soil contaminated with petroleum products. Biotechnology, 80(1), 97-108.

Nowak, A., Nowak, J., Hawrot-Paw, M., Telesiński, A., Błaszak, M., Kłódka, D., Przybulewska, K., Smolik, B., \& Szymczak, J. (2008). Biodegradation of diesel fuel in soils modified with compost or bentonite and with optimized strains of bacteria. Part II. Changes in microorganisms counts and activity. Ecological Chemistry and Engineering A, 15(7), 607-622.

Pala, D. M., de Carvalho, D. D., Pinto, J. C., \& Sant'Anna, G. L. (2006). A suitable model to describe bioremediation of a petroleum-contaminated soil. International Biodeterioration \& Biodegradation, 58(3-4), 254-260. https://doi. org/10.1016/j.ibiod.2006.06.026.

Pawełczak, M., Dawidowska-Marynowicz, B., Oszywa, B., Koszałkowska, M., Kręcidło, Ł., \& Krzyśko-Łupicka, T. (2015). Influence of bioremediation stimulators in soil on development of oat seedlings (Avena sativa) and their aminopeptidase activity. Archives of Environmental Protection, 41(1), 24-28. https://doi.org/10.1515/aep-20150003.

Robak, M., Boruczkowski, T., Drożdż, W., Lazar, Z., Baranowska, M., Prządo, D., \& Steininger, M. (2011). Application of the yeasts Yarrowia lipolytica for in-situ gioremediation of soil contaminated with creosote oil-a case study. Environmental Pollution Control, 33(2), 27-33.

Rosik-Dulewska, C., Krzyśko-Łupicka, T., Ciesielczuk, T., \& Kręcidło, Ł. (2015). Hydrogen peroxide as a biodegradation stimulator in remediation processes of soils heavily contaminated with petrochemicals. Polish Journal of Chemical Technology, 17(2), 17-22. https://doi.org/10.1515/pjct2015-0023.

Sirguey, C., de Souza e Silva, T. P., Schwartz, C., \& Simonnot, M. (2008). Impact of chemical oxidation on soil quality. Chemosphere, 72(2), 282-289. https://doi.org/10.1016/j. chemosphere.2008.01.027.

Van Hamme, J. D., Singh, A., \& Ward, O. P. (2003). Recent advances in petroleum microbiology. Microbiology and Molecular Biology Reviews, 67(4), 503-549. https://doi. org/10.1128/mmbr.67.4.503-549.2003.

Whiteley, C. G., \& Lee, D. J. (2006). Enzyme technology and biological remediation. Enzyme and Microbial Technology, 38(3-4), 291-316. https://doi.org/10.1016/j. enzmictec.2005.10.010.

Wolicka, D. (2010). Microorganisms in crude oil and formation waters. Oil-Gas, 4, 267-273.

Ziółkowska, A., \& Wyszkowski, M. (2008). Possibilities of neutralizing soils contaminated with petroleum-derived substances. Advances in Agricultural Sciences, 60(4-5), 33-45.

Publisher's Note Springer Nature remains neutral with regard to jurisdictional claims in published maps and institutional affiliations. 